BeATA GolińSKA

Uniwersytet Jagielloński

\title{
Some Remarks on the Studies of the Amazonian Prehistory
}

\begin{abstract}
Tn 1690, John Locke in his Two Treatises of Government wrote: “... in the beginning all the World was America" (Locke 1690). More than three centuries later, many still perceive Amazonia as nature in its purest form, a mysterious and wild land full of savage, "stone-age" Indians. However, the history of Amazonia is much more interesting and complex than it was thought before, and archaeological research reveals the relics of complex Pre-Columbian societies. Archaeology of tropical forests (Amazonian in particular) always languished at the periphery of modern studies, being a terra incognita on the archaeological world map. Owing to the most recent research, this previously neglected region rises to the role of an important cultural area.
\end{abstract}

\section{Ethnohistorical sources}

Traditionally, contemporary indigenous societies are seen by ethnographers as the descendants of populations inhabiting a given territory uninterruptedly for thousands of years. The same was claimed about Amazonian Indians. Although some native populations have survived till today, the Spanish Conquest transformed their lifestyle, economy, religion and traditions, creating completely new socio-cultural patterns. Therefore, any attempt to reconstruct life of Pre-Columbian peoples of Amazonia that relies on anthropological parallels only, will always be potentially flawed. This is also the case in archaeological research. By focusing on the analysis of artefacts only we lose information available in the macro scale. Help may come from historical sources, which provide 
much information about indigenous tribes of these regions. Moreover, chronicles and early travellers' accounts testify to the enormous impact of the Contact Period (after the arrival of the first Europeans) on the cultural situation in the Amazon forest.

Island societies of the Caribbean were the first groups whom the European travellers encountered in 1492. The knowledge about the groups inhabiting the continent came slightly later. The first European to see the Amazon river was Amerigo Vespucci, who sailed along the coasts of Brasilia and Guiana in 1499. However, it was a Spaniard, Vicente Yáñez Pinzón, who discovered "the queen of the rivers" several months later and named it Rio Santa Maria de la Mar Dulce. The name also appears on the Juan de la Cosa's map printed one year later (Davies 1956: 87). During their expedition, the Spaniards reportedly travelled 15 or 20 leagues upstream (Spanish: legua; English: league; Anglo-Saxon unit of length amounting to $4.8 \mathrm{~km}$. Spanish league, used until 1568, was $4.2 \mathrm{~km}$ ). They turned back because they found neither gold nor pearls, nor other valuables, but “just jungles and bellicose natives" (Barreto, Machado 2001: 236).

At first glance, the $16^{\text {th }}$ and $17^{\text {th }}$ century sources generate more questions than answers. The problem lies in the estimation of the size and development of the Pre-Columbian population. As the most recent archaeological research in Amazonia point to the the existence of large-scale indigenous complex societies, there is a need for reinterpretation of written accounts. At the beginning it should be mentioned that written sources are a kind of hybrid, a combination of their authors' experiences and expectations. As a completely "new world", Amazonia did not fit in well with the ideals. After the discoveries made in Mesoamerica or the Andes, people expected similar or even greater riches there. The confrontation between such big expectations and bitter disappointment gave rise to numerous legends and myths. Perhaps the most famous is that of the Amazons, who were already known from Greek mythology. Carvajal wrote about the warlike women: "[women warriors] fighting in front of all the Indian men as women captains", "Indian men did not dare to turn their backs, and anyone who did turn his back they killed with clubs right there before us" (Meggers 1971: 136). Portraying Amazonia as populated with imaginary, mythical creatures has created scepticism regarding the sources' credibility. Whatever the reasons for these fanciful borrowings (either to compensate for the failure of an expedition or to present discoveries as more interesting or exotic to spark monarchs' and other audiences' imagination), they should not overshadow another important observation - an amazement and admiration for the newly found world. These narratives are of fundamental importance for studying the $16^{\text {th }}$ and $17^{\text {th }}$ century Amazonia.

In 1500, the Portuguese fleet bound for India landed on the north-eastern coast of Brasilia (Whitehead 1999: 418). The crew was greeted by a group of Indians, whom Pedro Vas de Caminha described in his letter to Manuel I, the King of Portugal, in the following way: "people who were as innocent as Adam and Eve before the Fall and blissfully free from sexual self-consciousness. Men and women alike walked about naked wearing only red and black body paint and adornments 
of feathers and string, feeling no shame whatsoever" (MacCormak 1999: 102). Their life was close to the representation of paradise. Convinced that the Indians might become devout Christians, Vas de Caminha regarded Brasilia as a promise of the imminent restoration of paradise (MacCormak 1999: 102).

In February 1541 the first expedition was launched, in search of lands of cinnamon (La Canela) and El Dorado. The expedition was led by Gonzalo Pizarro, the half-brother of Francisco Pizarro. Leading a squad of more than two hundred mounted soldiers and four thousand native slaves, he left Quito and marched eastward, over the Andes, discovering a "mighty, meandering river" (Grann 2010: 188190). As the expedition was running out of food, Pizarro divided the party into two groups. The first group travelled along the river on land. The second group, of more than fifty Spaniards led by Francisco de Orellana, built a boat and headed down the river in hope of finding food. One of the expedition members was a Dominican monk, Gaspar de Carvajal, whose chronicle provides the most extensive information about numerous native villages along the Amazon river. The original of his work entitled Descubrimiento del famosorio Grande de las Amazonas is kept in the Academy of History of Madrid. Carvajal's chronicle is known in two versions: the first one was used by Gonzalo Fernández de Oviedo in his Historia general y natural de las Indias, and the second was published by Toribio Medina in 1894. After a long career in the Indies, Gonzalo Fernández de Oviedo became a governor of a Spanish fortress in the island of Santo Domingo, where he resided since 1533. His island was often visited by the expeditions sailing to or from Amazonia, and his notes are full of the travellers' descriptions of numerous indigenous societies (MacCormak 1999: 100).

Densely populated indigenous settlements of substantial size are mentioned very often in such early narratives. Bewilderment and surprise caused by the scale of this phenomenon permeate almost every account of such travellers as Gaspar de Carvajal, Francisco Vasquez (member of the 1559-1561 expedition), Alonso de Rojas (author of a diary recounting the expedition of 1639-1640) or Cristobal de Acuña (1641). Rojas mentions that the riverbanks and islands were so densely populated "that if you threw a needle up in the air, it would fall on the head of an Indian and not on the ground" (de Oliveira 1994: 96). Remarks such as "villages extended for about eighty leagues", "very big province", "very numerous and large settlements, "we continued to pass by numerous and very large villages (...) and the further we went, the more thickly populated (...)" are repeated in virtually every description (Barreto\& Machado 2001: 236-237). Surprise and wonder are sometimes explicit in the chronicles. Some of the inhabited regions "were so large they stirred up fear [in us]", and on reaching a group of large islands, possibly near the Tapajós "so numerous were the settlements, which came into sight and which we distinguished on the said island that we were grieved; and they saw us, there came out to meet us on the river over two hundred pirogues, that each one carries twenty or thirty Indians and some forty (...)" (Carvajal; Barreto, Machado 2001: 237). Apart from extensive settlement, chroniclers often commented on social and political structures of Amazonia. Naming the leaders, chiefs 
or overlords, they emphasized their authority and power. Indigenous material culture and their vast knowledge about nature and environment also inspired respect. Carvajal mentions pottery of unique quality: "They manufacture and fashion large pieces out of clay, with relief designs, [in the style of] Roman workmanship; and so it was that we saw many vessels, such bowls and cups and other containers for drinking, and jars as tall as a man (...) very beautiful and made out of a very fine quality of clay" (Meggers 1971: 134).

Even though we know early chroniclers' and travellers' accounts of the societies they encountered, it is nevertheless difficult to interpret the territorial divisions, political organization and religious institutions in terms of western terminology. Anthropological studies offer some help here. The $16^{\text {th }}$ and $17^{\text {th }}$-century chroniclers perceived the mosaic of languages and tribes of Amazonia through the prism of the division into language families. Father Christobal de Acuña in his report from the Pedro Teixeira's voyage notes that „all this new world (...) is inhabited by barbarians of distinct provinces and nations (...). There are over hundred and fifty, all with different languages" (de Oliveira 1994: 96).

The analysis of ethnohistorical record as well as modern anthropological research allows us to better understand the processes that shaped prehistoric societies of Amazonia. The majority of coastal groups who shared almost all cultural attributes became known as the Tupi, and their language was described as lingua geral da costa. Early descriptions of South American peoples were based on geographical and political criteria interrelated with indigenous cultural geography. In mid- $17^{\text {th }}$ century, the Atlantic coast of Brasilia, between the La Plata and the Amazon rivers, was dominated by the Tupinambá, who were mentioned along with the Tupi in many northern regions of South America. This provides evidence for migrations of these groups long before the arrival of the Europeans. The spread of groups belonging to one language family over the entire Amazonia was a very common phenomenon in the history of the region. Anthropological and archaeological records suggest that Amazonia witnessed numerous migratory movements in the past. Between the second quarter of the $17^{\text {th }}$ century and the early $18^{\text {th }}$ century we can speak of a whole series of translocations across Amazonia rather than of single migrations.

\section{Archaeological sources}

The earliest Ceramic sites

Until recently, it has been assumed that the earliest pottery in the New World was associated with the sites in Ecuador (Valdivia) and Columbia (Puerto Hormiga and Monsu). However, the most recent research indicates that the earliest vessels appeared in Amazonia (Caverna da PedraPintada, Taperinha) between 8000 and 7000 years ago (Roosevelt 1995: 123). Pottery also appeared in lower Amazonia, on the Guiana coast, on the Xingu and Januari rivers, always within 
midden mounds called sambaquis (Neves 2008: 365). The appearance of the earliest pottery on sites with shellmounds was connected with the intensive exploitation of renewable aquatic resources.

Early ceramic complexes are not identical. PedraPintada and Taperinha are characterised by relief decoration and sand temper, while the sites on the Jauari and Xingu rivers, at the Atlantic coast and in eastern Guiana reveal no such decoration and the temper is mostly shell.

The excavations conducted in the 1970's and 1980's on seven sambaquis from eastern South America produced over thirty radiocarbon dates for pottery from this region (Roosevelt 1995: 116). Vessels originating from the period between 6000 and 4000 years ago turned out to be 500 or sometimes even 1000 years older than the oldest analogical complexes from Ecuador and Colombia (3000 BC; Lathrap 1970), which had been so far considered to be the earliest in South America.

The appearance of the earliest pottery on sites clustered around Santarém, on other unrelated shellmounds in southern Brasilia, as well as in Columbia and Ecuador suggests an independent development of these complexes. We can therefore assume that the pottery traditions in Amazonia were developing independently in several regions, more or less simultaneously.

\section{Cultural diversity}

A thousand years before the Conquest, supra-regional stylistic horizons with elaborate geometric-zoomorphic imagery developed in Lower and Central Amazonia. Decoration types gave ground for identifying four Pan-Amazonian horizons of pottery: Zoned-Hachured Horizon, Incised Rim Horizon, Amazonian Polychrome Horizon and Incised-Punctuate Horizon (Neves 2008: 365). This division, and the changes in decoration and style of ceramic vessels, are the foundations for the entire Amazonian chronology. "Horizons" and "styles", used as synonyms, are the equivalent of such terms as "traditions" or "complexes" used by European archaeologists. Therefore, a "horizon" should not be identified with a particular archaeological culture. It should rather be regarded as a manifestation of stylistic (and perhaps ideological) patterns spreading across Amazonia. At present, we cannot be sure whether the cultures representing these horizons developed from earlier local traditions or were the new patterns introduced via migration. The fact remains that during the time of these horizons the subsistence patterns changed. Hunting and gathering was replaced by agriculture, supplemented with hunting-gathering-fishing economy. In some parts of Amazonia, considerable changes also occurred in the organisation, size and functioning of indigenous societies, leading to the development of chiefdoms (Roosevelt 1993: 259).

The earliest horizon, the Zone-Hachured Horizon, appeared on the lower Amazon river c. 1400 BC (Fiedel 2003: 204). The place of its origin is difficult to identify; it is best represented in the materials from Marajó Island (1400-910 BC; Evans, Meggers 1957; Simões 1969). 
In the $5^{\text {th }}$ century $A D$, large sites with pottery attributed to the Incised Rim Horizon developed in central Amazonia. Diagnostic traits of this style are vessel decoration with incised curved ornaments and modelled appliqués representing animals or human faces (adornos).

In the first millennium $\mathrm{AD}$, two processes were characteristic of central Amazonia: the development of local cultural traditions and a significant demographic growth. With the beginning of the second millennium AD a new cultural-chronological tradition emerged, replacing the Incised Rim pottery with new vessels representing the Amazonian Polychrome. It was the first stylistic tradition to be present in almost the entire Amazonia, from the eastern Andean slopes in Peru, Ecuador or Columbia, to the eastern coasts of Brasilia. This tradition was represented by such complexes as Marajoara (Marajó Island), Guarita (central Amazonia), Aristé (state of Amapa), Rio Napo (Ecuador) and Araracuara (on the Rio Caqueta, Columbia; Evans, Meggers 1957; Roosevelt et al. 1991; 1999; Schaan 2004). The Polychrome horizon brought a real explosion of decorative motifs. Vessels with red and/or black motifs painted against white background are the diagnostic form for this horizon and have been known to be found in the entire Amazonia. Relief decoration, incision, modelling, and grooving also appear. The earliest Amazonian Polychrome vessels come from the sites on the upper Madeira (250 AD) and from Marajó Island (400 AD; Boomert 2004: 259; Roosevelt 1991: 313-314; Schaan 2001: 1570). Based on just a preliminary analysis of ceramic materials from that area, we can follow the whole creation of this horizon. Proceeding from the pottery studies (preliminary seriation method) Evans and Meggers (1957) identified five chronological phases for the region. Only one of them, Marajoara (400-1350 AD), represented a high level of socio-political development. The Marajoara society, hierarchized and stratified, was divided into elites and common people. Social status was reflected in access to and control of natural resources, access to the supernatural world and to prestige goods, i.e. decorated pottery (Schaan 2004). It seems that pottery was manufactured locally, within households and, even though some more refined vessels are thought to be produced by specialized potters, it was only a seasonal, prestigious activity. The largest number of ceramic objects comes from the graves. The deceased were buried in urns, placed in pits dug in the floors of houses or temples. The urns were covered with lids or inverted bowls. They were not covered with soil and remained visible (Schaan 2001; 2008). Rich iconography plays an important role in understanding the nature of the Marajó societies (Roosevelt 1991). Ceramic objects of the Marajoara refer to ancestor worship and a strong belief in the afterlife.

According to Meggers and Evans, the Amazonian Polychrome was followed by the Incised-Punctuate Horizon (Roosevelt 1999). Traditionally, anthropomorphic stone figurines (McEwan 2001; Barreto, Machado 2001; Neves et al. 2001) and small stone amulets, anthropomorphic or zoomorphic, called muiraquitãs were associated with the sites representing this horizon. These objects are widespread in Amazonia and in the northern part of South America (Neves 2008). 
The beginnings of this tradition are still obscure. Many pottery features (modelling, incisions) are shared with early ceramic complexes from the northern part of South America (Neves 2008). The closest parallels come from the Arauquinoid pottery (400-1400 AD), from the areas on the Middle Orinoco and on the coasts of Suriname and French Guiana (Rostain\&Versteeg 2004).

\section{Anthropological and linguistic data}

The issues of pottery, its origin and ethnicity of Amazonian Horizons sparked a hot debate among archaeologistssince the 1960's. Meggers and Evans proved the existence of foreign impulses which led to the formation of the ceramic tradition in the north-eastern Amazonia (Evans and Meggers 1950, 1957a, 1957b). Lathrap (1970) and others (Gasson 2002; Neves 2008; Wilson 2007) demonstrated great importance of linguistic migrations that spread throughout the Amazon. The period presented above was the time of cultural and ethnolinguistic transformations that were unprecedented in the history of Amazonia. It is assumed that migratory movements of groups speaking various languages were strongly reflected in the imagery of the Amazonian pottery (Lathrap 1970). Other scholars, like Roosevelt (1993), were looking for local influences in ceramic traditions. We do not know what ethnic and political processes led to the emergence of ceramic horizons (Whitehead 1993). However, none of theory described above has been confirmed by the source material analysis.

The greatest problem that presents itself to the researchers are the two cultural-chronological traditions which emerged with the first millennium A.D.: the Amazonian Polychrome Tradition and the Incised-Punctuate Horizon, the first stylistic traditions that have spread throughout almost the entire area of the north-eastern Amazonia.

Initially, it was assumed that the Incised Rim Horizon developed from local traditions. However, this theory has attracted widespread criticism now. Supporters of the Central-Amazonian origins have been arguing that the population using incised decoration migrated from central Amazonia towards the Rio Negro, Orinoco and Caribbean - a process supposedly reflected in archaeological record of pottery found on the Orinoco (Barrancoid; Lathrap 1970). In their opinion, the Barrancoid horizon developed from the earlier tradition of the Incised Rim. However, archaeological evidence speaks against this view - the Barrancoid sites in the Orinoco basin are earlier than the Incised Rim sites on the central Amazon (Neves 2008). On the other hand, a striking similarity between the two complexes should not be ignored. Perhaps, in order to explain their genesis, we should reject the concept of Central-Amazon origins and accept the view proposed by Meggers, who saw the origins of this early pottery in northern Columbia (Neves 2008: 367).

We do not know what ethnic and political processes led to the emergence of the Amazonian Polychrome Horizon. Lathrap, Brochado and Oliver suggest that the development and spread of the Amazonian Polychrome was related 
to migration of a single ethnic or linguistic group. Whitehead (1994) refutes this explanation, claiming that around $14^{\text {th }}-15^{\text {th }}$ century Amazonia was a multi-ethnic area and, therefore, linking the expansion of polychrome decoration with migration of a single linguistic group is highly problematic. On the other hand, it is argued that in the discussed period in Amazonia was the time of major migratory movements (Arawak, Tupi-Guarani), each of which brought about changes in material culture (Neves2008: 368). As the appearance of Polychrome pottery correlates with the development of agriculture and the intensified construction of raised fields, some researchers suggest that the early Amazonian Polychrome migration was responsible for the introduction of manioc and peach-palm cultivation by the populations being part of the Tupi linguistic group about 2500 years ago (Neves 2008: 369).

The Incised-Punctuate Horizon and the Arauquinoid pottery on the Orinoco are supposed to be local manifestations of the Karibi-speaking population spreading in the early first millennium AD (Neves 2008: 370).

\section{Environmental studies}

Studies on the environment and its modification by the former communities of tropical forest area play a unique role in understanding the Amazonian prehistory. A typical archaeological site in the Amazonia presents a unique combination of black earth, pottery shards and characteristic plant species that William Bale called "cultural forest" (Schaan et al. 2009: 127). The intensive use of river resources, manioc and maize cultivation (Roosevelt 1980, 1991) enabled the development of sedentary lifestyle (Lathrap 1970).The most evident argument for the presence of large groups of people in the Amazonia are patches of "black earth" (Amazonian Dark Earths, ADE), especially its variation - terrapreta ("black earth", terra preta do indio - „Indian black earths”; terra preta antropogenica - "anthropogenic black earth" or terra preta arqueologica - "archaeological black earth"; Petersen et al. 2001: 86; Sombroek et al. 2002: 2; Kampf et al. 2003: 78; Lehmann et al. 2003: 105; Woods et al. 2004: 3; Lehmann 2006: 624). Amazonian Dark Earths are considered to be the result of past presence of indigenous population, who more or less consciously enriched the soil with charcoal, organic waste and ceramic shards. Very dark color, a great amount of broken pot shards, highly elevated level of land, and increased concentration of organic matter are the characteristics that make ADE extremely fertile.

ADE prove the existence of large and numerous prehistoric settlements in Amazonia, and they are an artifact in itself. The size and shape of Amazonian anthropogenic soil sites can be compared to the historical traces of the indigenous settlement of the rainforest (Myers et al. 2003: 19). On a large scale, ADE occurred between 450 BC and 950 AD (Petersen et al. 2001: 100; Erickson 2003: 484; Neves et al. 2003). In most cases, the earliest dates come from the Central and Lower Amazon River and are associated with the spreading of multi-colored, 
polychrome pottery belonging to the Amazonian Polychrome Tradition (Lathrap 1970; Erickson 2003: 484; Roosevelt 1991; Petersen et al. 2001, Myers et al. 2003, Neves et al. 2003). Today, most researchers believe these changes to be associated with increasing population pressure on the environment and increased social interaction (Lathrap 1970; Oliver 2001; Petersen et al. 2001).

Amazonian Dark Earth are ubiquitous at archaeological sites in the Amazonia and covered 0.1 to $0.3 \%$ of the Amazon region, which is from 6 to18 thousand km2of forested areas of lowland Amazonia (Erickson 2003: 463; Sombroek et al. 2003; Woods et al. 2009: 1). According to other estimates, the total area of soil partially or completely anthropogenic covers more than $10 \%$ of the entire Amazonia. This includes areas used for cultivation, uplands related to the aquatic economies and, finally, terras pretas and terras mulatas (Hecht 2003:356). Due to relatively small size when compared to the surrounding soils, ADE occur on soil maps only as inclusions. Over $80 \%$ of ADE areas cover less than 2 hectares, only a few reach several hundreds of acres (500 ha - Santarém, Belterra 200 ha, 80 ha Manacapuru, 90 ha of Altamira, Erickson 2003: 463; Kern et al. 2003: 68; Woods et al. 2004: 3; Schaan et al. 2009: 128; Woods 2009: 2).

Early scholars and explorers reported densely populated villages extending along the river, running sometimes for several kilometers, and a thick network of roads connecting big settlement clusters located more inland. Research indicates that terra preta can coincide with the location of those settlements (Woods et al. 2004: 3). Thus came the idea of anthropogenic nature of these soils. Specification of terras pretas, high concentration of charcoal and the frequent occurrence of pottery fragments and stone artifacts seem to confirm this hypothesis.

In contrast with the otherwise infertile Amazonian soil, ADE are highly fertile (Glaser et al. 2004: 9) and can be found practically on its entire territory. The problem with its origins and a role they have played in the cultural processes in the pre-Columbian period have been discussed for years among a broad group of archaeologists, anthropologists and soil scientists.

\section{Final Remarks}

Growing interest in archaeology, the accumulation of new archaeological research and the emergence of new information, led to the necessity of reinterpretation of current theories and knowledge. Due to constant data inflow, the search for new directions of development has become compelling in archaeology. The methods once developed for a given region need not prove appropriate somewhere else. This is particularly true for the archaeology of the Amazonia. Archaeology of Amazonian tropical forests always languished at the periphery of modern studies. Many perceived Amazonia as an environment poor in resources, a "false paradise" (Meggers 1971). Complex prehistoric societies were attributed to intrusions from other populations, mainly from the central Andes (Roosevelt 1999: 308). Typical ways of life and subsistence of Amazonian Indians, i.e. living in small groups 
in independent egalitarian communities and villages, were related to historical times as the product of the devaluated Andean culture (Meggers 1954; Meggers 1971; Roosevelt 1999: 308). Owing to the most recent research, this previously neglected region rises to the role of an important cultural area. Unfortunately, some of the methods of archaeological analysis used in this particular area are still far from being sufficient. Other important problem in this field of studies is the prevalence of macro-scale studies and neglect of detailed technological and typological analysis on micro-scale. This is the case for studies on ceramic products in general. We lack comprehensive research and analyses of micro-scale processes. Unfortunately, the archaeology of Amazonia is still poorly represented in the Polish literature. This paper aimed to fill this gap in the Polish archaeological literature.

Proceeding from the results of archaeological, anthropological and environmental studies, I have tried to characterise the pre-European communities of the Brazilian Amazonia and demonstrate that tropical forest was the habitat enabling development of complex societies. The topic of this article was intended to be an introduction to the issue of the Amazonian Cultural Area and an invitation to further debate. My own research interests and studies focus on Amazonian pottery.

The history of research on Amazonian ceramic products is almost as long as the Amazonian archaeology itself. Major publications concerning pottery from the area appeared in the late 1940s, when scholars in the filed started to link ceramic artifacts to foreign influences. In 1970 Donald Lathrap (Lathrap 1970) published his influential book, in which he linked ceramic production with migration of different linguistic groups. Since then we have observed increased interest in research to support Lathrap's theory. Most of these studies, however, have been limited to an analysis of iconography, without technological analysis of ceramic artifacts. Of course, the iconography plays an important role in reconstructing the past of pre-Columbian societies. Nevertheless, there is a necessity of basic studies synthesizing technological and iconographical spheres. Large part of the hypotheses were constructed as a working hypothesis before the detailed analysis were made. The project is a response to the need of reinterpretation of the hypothesis concerning all aspects of ceramic materials.

Preliminary studies on ceramic products provided grounds for identifying different pottery traditions of the Amazonia. A thousand years before the Conquest, supra-regional stylistic horizons with elaborate geometric-zoomorphic imagery developed in Lower and Central Amazonia. Decoration types provided grounds for identifying four Pan-Amazonian horizons of pottery: Zoned-Hachured Horizon, Incised Rim Horizon, Amazonian Polychrome Horizon and Incised-Punctuate Horizon (Neves 2008). With the beginning of the second millennium A.D. a new cultural-chronological tradition emerged, with new vessels representing the Amazonian Polychrome Tradition (Roosevelt 1993). It was the first stylistic tradition to be present practically in the entire north-eastern Amazonia. The Polychrome horizon brought a real explosion of decorative motifs. 
The Amazonian Polychrome was followed by the Incised-Punctuate Horizon, which began in the early first millennium A.D. (Young-Sanchez, Schaan 2011). This division, and studies focusing on the changes in decoration and style of ceramic vessels, are the foundations for the entire Amazonian chronology (Meggers 1948; Meggers, Evans 1980; Meggers et al. 1965; Roosevelt 1993). I believe, that both traditions are artificial creations within which all objects sharing a general similarity of decoration have been included. Given the lack of a detailed analysis of ceramic materials, it is difficult to hypothesize about local differences and differences in decorating changes within specific horizons. Therefore, pottery classification requires revision and detailed analysis based on studies of ceramic artefacts.

Moreover, "horizons" and "styles", used as synonyms, are the equivalents of such terms as "traditions" or "complexes" used by European archaeologists. Therefore, after a preliminary analysis, I assume that a "horizon" should not be identified with a particular archaeological culture. It should, rather, be regarded as a manifestation of stylistic and ideological patterns spreading across Amazonia. No further studies based on detailed methods of analysis and technological studies have been published so far. The aim of my research is to go beyond the theories and current classifications, and formulate new, comprehensive and complete method of analyzing the full scope of aspects of the ceramic production. The goal is to create new classification of ceramic products based on archaeological sources. The analysis of the chronology and typologies will be the starting point of the project. The new analysis will lead to answers about wider processes of change in manufacturing, changes in decoration and stylistics and, finally, the iconographical shift.

The analysis of the concepts presented above aimed to underline how much space is devoted to ceramic products as artifacts. Current classifications concern mainly the macro-scale processes. Researchers forget about the necessity to carry out detailed and accurate analysis of technology used during ceramic production. The necessity to use the latest methods of archaeological documentation has also been neglected. In modern Amazonian archaeology this type of study has not been applied, nor has the methodology of research on ceramic manufacturing been fully created. Therefore, the project will focus primarily on ways of working with ceramic materials. The analysis of all aspects of the manufacturing process is needed before proceeding to the analysis of iconography, stylistics and symbolism. In this approach, stylistics is understood as a set of decorations and arrangement of created motifs. The iconography includes a symbolic sphere of the artifact providing a link to the broader symbolic context of art. We are only beginning to understand the Amazonian past. To a large extent, the region of such potential remains unexplored. Over time, forest covered the relics of archaeological societies of Amazonia, hiding from the world what was the most beautiful and mighty in its past. 


\section{References}

Barreto, C., Machado, J. (2001). Exploring the Amazon, Explaining the Unknown: Views from the Past. In: C. McEwan, C. Barreto, E. G. Neves (eds.), Unknown Amazon. Culture in Nature in Ancient Brazil (pp. 232-251). London: The British Museum Press.

Boomert, A. (2004). Koriabo and the Polychrome Tradition: the late-prehistoric era between Orinoco and Amazon mouths. In: A. Delpuech, C.L. Hofman (eds.), Large Ceramic Age Societies in the Eastern Caribbean (pp. 251-266). BAR International Series 1273, Paris Monographs in American Archaeology 14. Oxford: Archaeopress.

Davies, A. (1956). The First Discovery and Exploration of the Amazon in 1498-99. Transactions and Papers (Institute of British Geographers), 22, 87-96.

de Oliveira, A.E. (1994). The evidence for the Nature of the Process of Indigenous. Deculturation and Destabilization in the Brazilian Amazon in the Last Three Hundred Years: Preliminary Data. In: A.C. Roosevelt (ed.), Amazonian Indians from Prehistory to the Present. Anthropological Perspectives (pp. 95-122). Tuscon: The University of Arizona Press.

Erickson, C.L. (2003). Historical Ecology and Future Explorations. In: J. Lehmann et al. (eds.), Amazonian Dark Earths: Origin, Properties, Management (pp. 455-500). Dordrecht: Kluwer Academic Publisher.

Evans, C., Meggers, B.J. (1950). Preliminary Results of Archaeological Investigations at the Mouth of the Amazon. American Antiquity, 16(1), 1-9.

Evans, C.; Meggers, B. J. (1957). Formative Period Cultures in the Guayas Basin, Coastal Ecuador. American Antiquity, 22(3), 235-247.

Fiedel, S.J. (2003). Prehistory of the Americas. 2nd ed. Cambridge: Cambridge University Press.

Gasson, R.A. (2002). Orinoquia: The Archaeology of the Orinoco River Basin. Journal of World Prehistory, 16(3), 237-311.

Glaser, B., Zech, W., Woods, W.I. (2004). History, Current Knowledge and Future Perspectives of Geoecological Research Concerning the Origin of Amazonian Anthropogenic Dark Earths (Terra Preta). In: B. Glaser, W.I. Woods (eds.), Amazonian Dark Earths: Explorations in Space and Time (pp. 10-17). Berlin: Springer.

Gomes, C.D.M. (2002). Cerâmica arqueológica da Amazônia: vasilhas da Coleção Tapajônica MAE-USP. São Paulo: FAPESP/EDUSP/ Imprensa Oficial de São Paulo.

Grann, D. (2010). Zaginione miasto Z. Amazońska wyprawa tropem zabójczej obsesji. Warszwa: Wydawnictwo W.A.B.

Hecht, S.B. (2003). Indigenous Soil Management and the Creation of Amazonian Dark Earths: Implications of Kayapó Practices. In: J. Lehmann (ed.), Amazonian Dark Earths: Origin, Properties, Management (pp. 355-372). Dordrecht: Kluwer Academic Publisher.

Kämpf, N. et al. (2003). Classification of Amazonian Dark Earths and other Ancient Anthropic Soils. In: J. Lehmann (ed.), Amazonian Dark Earths: Origin, Properties, Management (pp. 77-104). Dordrecht: Kluwer Academic Publisher.

Lathrap, D. (1970). The Upper Amazon. London: Thames \& Hudson.

McEwan, C. (2001). Seats of Power: Axiality and Access to Invisible Worlds. In: C. McEwan, C. Barreto, E.G. Neves (eds.), Unknown Amazon.Culture in Nature in Ancient Brazil (pp. 176-197). London: The British Museum Press.

Lehmann, J. (2006). Black is the new green. Nature, 44, 624-626.

Lehmann, J. et al. (2003). Soil Fertility and Production Potential. In: J. Lehmann (ed.), Amazonian Dark Earths: Origin, Properties, Management (pp. 105-124). Dordrecht: Kluwer Academic Publisher. 
Locke, J. (1690). Dwa traktaty o rządzie, www.gutenberg.org/ebooks/7370 [accessed on: 10.02.2017].

MacCormack, S. (1999). Ethnography in South America: The First Two Hundred Years. In: F. Salomon, S.B. Schwartz (eds.), Cambridge History of the native peoples of the Americas. Vol. 3. South America (pp. 96-187). Cambridge: Cambridge University Press.

Meggers, B.J. (1948). Archaeology of the Amazon Basin. In: J.H. Steward (ed.), Handbook of South American Indians. Vol. 3. The tropical forest tribes (pp. 149-166). Washington D.C.: U. S. Government Printing Office.

Meggers, B.J. (1954). Environmental Limitation on the Development of Culture. American Anthropologist, New Series 56(5), 801-824.

Meggers, B.J. (1971). Amazonia: Man and Culture in a Counterfeit Paradise. Wheeling: Harlan Davidson.

Meggers, B.J., Evans, C. (1980). Unmetodoceramicopara el reconocimiento de comunidades pre-historicas. Boletin del Museu del Hombre DominicanoAno, 9(14), 57-73.

Meggers, B.J., Evans, C., Estrada, E. (1965). Early Formative Period of Coastal Ecuador: the Valdivia and Machalilla phases. Washington D.C.: Smithsonian Institution. Contributions to Anthropology 1.

Myers, T.P. et al. (2003). Historical Perspectives on Amazonian Dark Earths. In: J. Lehmann et al. (eds.), Amazonian Dark Earths: Origin, Properties, Management (pp. 16-29). Dordrecht: Kluwer Academic Publisher.

Neves, E.G., Barreto, C., Neves, E.G. (2001). Introduction. In: C. McEwan, C. Barreto, E.G. Neves (eds.), Unknown Amazon.Culture in Nature in Ancient Brazil (pp. 14-23). London: The British Museum Press.

Neves, E.G. et al. (2003). Historical and Socio-cultural Origins of Amazonian Dark Earths. In: J. Lehmann et al. (eds.), Amazonian Dark Earths: Origin, Properties, Management (pp. 30-50). Dordrecht: Kluwer Academic Publisher.

Neves, E.G. (2008). Ecology, Ceramic Chronology and Distribution, Long-term History, and Political Change in the Amazonian Floodplain. In: H. Silverman, W.H. Isbell (eds.), Handbook of South American Archaeology (pp. 359-380). Berlin: Springer.

Oliver, J.R. (2001). The Archaeology of Forest Foraging and Agricultural Production in Amazonia. In: C. McEwan, C. Barreto, E.G. Neves (eds), Unknown Amazon. Culture in Nature in Ancient Brazil (pp. 50-85). London: The British Museum Press.

Petersen, J.B., Neves, E.G., Heckenberger, M.J. (2001). Gift from the Past: Terra Preta and the Prehistoric Amerindian Occupation in Amazonia. In: C. McEwan, C. Barreto, E.G. Neves (eds.), Unknown Amazon. Culture in Nature in Ancient Brazil (pp. 86-107). London: The British Museum Press.

Roosevelt, A.C. (1980). Parmana. Prehistoric Maize and Manioc Subsistence along the Amazon and Orinoco. Cambridge: Academic Press, Inc.

Roosevelt, A.C. (1991). Moundbuilders of the Amazon. Geophysical Archaeology on Marajó Island, Brazil. Cambridge: Academic Press, Inc.

Roosevelt, A.C. (1993). The Rise and Fall of the Amazon Chiefdoms. L'Homme, 33(126), 255-283.

Roosevelt, A.C. (1995). Early Pottery in the Amazon. Twenty Years of Scholarly Obscurity. In: W.K. Barnett, J.W. Hoopes (eds.), Emergence of pottery. Technology and Innovation in Ancient Societies (pp. 115-131). Washington D.C.: Smithsonian Institution Press.

Roosevelt, A.C. (1999). The Maritime, Highland, Forest Dynamic and the Origins of Complex Culture. In: F. Salomon, S. B. Schwartz (eds.), Cambridge History of the Native peoples of the America. Vol. 3, Part 1 (pp. 264-349). Cambridge: Cambridge University Press. 
Rostain, S., Versteeg, A.H. (2004). The Arauquinoid Tradition in the Guianas. In: A. Delpuech, C.L. Hofman (eds.), Large Ceramic Age Societies in the Eastern Caribbean. BAR International Series 1273, Paris Monographs in American Archaeology 14 (pp. 233-250). Oxford: Archaeopress.

Schaan, D. (2001). Into the Labyrinths of Marajoara Pottery: Status and Cultural Identity in Prehistoric Amazonia. In: C. McEwan, C. Barreto, E.G. Neves (eds.), Unknown Amazon. Culture in Nature in Ancient Brazil (pp. 108-133). London: The British Museum Press.

Schaan, D. (2004). The Camutins chiefdom rise and development of social complexity on Marajó island, Brazilian Amazon, PhD dissertation. Pittsburgh: University of Pittsburgh.

Schaan, D.P., Kern, D.C., Frazão, F.J. L. (2009). An Assessment of the Cultural Practices Behind the Formation (or Not) of Amazonian Dark Earths in Marajó Island Archaeological Site. In: W.I. Woods et al. (eds.), Amazonian Dark Earths: Wim Sombroek's Vision (pp. 127-142). Berlin: Springer.

Simões, M.F. (1969). The Castanheira Site: New Evidence on the Antiquity and History of the Ananatuba Phase (Marajo Island, Brazil). American Antiquity, 34(4), 402-410.

Sombroek, W. et al. (2002). Terra preta and terra mulata: pre-Columbian Amazon kitchen middens and agricultural fields, their sustainability and their replication, research paper delivered at the 17th World Congress of Soil Science, Bangkok-Thailand, 14-20 August 2002.

Sombroek, W. et al. (2003). Amazonian Dark Earths as Carbon Stores and Sinks. In: J. Lehmann et al. (eds.), Amazonian Dark Earths: Origin, Properties, Management (pp. 125-140). Dordrecht: Kluwer Academic Publisher.

Whitehead, N.L. (1994). The Ancient Amerindian Polities of the Amazon, Orinoco and Atlantic Coast: A Preliminary Analysis of Their Passage from Antiquity to Extinction. In: A.C. Roosevelt (ed.), Amazonian Indians from Prehistory to the Present. Anthropological Perspectives. Arizona: The University of Arizona Press.

Whitehead, N.L. (1993). Ethnic Transformation and Historical Discontinuity in Native Amazonia and Guayana, 1500-1900. L'Homme, 33(126), 285-305.

Whitehead, N.L. (1999). Native Peoples Confront Colonial Regimes in Northeastern South America (c. 1500-1900). In: F. Salomon, S.B. Schwartz (eds.), Cambridge History of the Native Peoples of the Americas. Vol. 3. South America (pp. 382-442). Cambridge: Cambridge University Press.

Wilson, S.M. (2007). The Archaeology of the Caribbean. Cambridge: Cambridge University Press.

Woods, W.I., Glaser, B. (2004). Towards an Understanding of Amazonian Dark Earths. In: B. Glaser, W.I. Woods (eds.), Amazonian Dark Earths: Explorations in Space and Time (pp. 1-8). Berlin: Springer.

Young-Sanchez, M., Schaan, D. (2011). Marajó: Ancient Ceramics from the Mouth of the Amazon. Denver: Denver Art Museum.

\section{SUMMARY}

\section{Some Remarks on Studies on the Prehistory of Amazonia}

The subject of the article was intended as an introduction to the issue of the Amazonian Cultural Area and the matter of debate. Owing to the most recent archaeological research, previously neglected region rises to the role of an important cultural area. The history of research on Amazonian ceramic products is almost as long as the Amazonian 
archaeology itself. Preliminary studies on ceramic products gave ground for identifying pottery traditions of the Amazonia which led to the creation of the chronology of the studied area.

Keywords: archaeology, ethnohistory, environmental studies, pottery, iconography. 